\title{
(2) OPEN ACCESS \\ Idiopathic multicentric Castleman disease preceded by cutaneous plasmacytosis successfully treated by tocilizumab
}

\author{
Tetsuro Aita, Sugihiro Hamaguchi 다, Yoko Shimotani, Yohei Nakamoto
}

Department of General Internal Medicine, Fukushima Medical University, Fukushima, Japan

\section{Correspondence to}

Professor Sugihiro Hamaguchi; fmu-gim@fmu.ac.jp

Accepted 5 October 2020

Check for updates

(c) BMJ Publishing Group Limited 2020. Re-use permitted under CC BY-NC. No commercial re-use. See rights and permissions. Published by BMJ.

To cite: Aita T, Hamaguchi S, Shimotani Y, et al. BMJ Case Rep 2020;13:e236283. doi:10.1136/bcr-2020236283

\section{SUMMARY}

A woman aged 45 years with a 1.5-year history of violaceous plaques on the forehead and chest presented with fever, weight loss and aggravation of the plaques. Inflammatory markers and interleukin- 6 level were elevated, and superficial lymphadenopathies and splenomegaly were identified by CT scan. Immunohistochemical findings of the lymph node and the skin showed polyclonal plasmacytosis and follicular hyperplasia, leading to the diagnosis of idiopathic multicentric Castleman disease (iMCD) after human herpesvirus-8 infection was excluded. The patient was successfully treated with anti-interleukin-6 receptor antibody, tocilizumab, following relapse after prednisolone therapy.

Our literature review found 11 case reports of pathologically confirmed iMCD preceded by cutaneous plasmacytosis. The median duration of asymptomatic phase with only skin lesions was 7.5 years, whereas the phase lasted only for 1.5 years in our case. iMCD can develop shortly after asymptomatic cutaneous plasmacytosis. Tocilizumab can be a treatment of choice for this type of iMCD.

\section{BACKGROUND}

Multicentric Castleman disease (MCD) is a polyclonal lymphoproliferative disorder characterised by multiple lymphadenopathies with systemic inflammatory symptoms. The disease is classified according to the presence or absence of human herpesvirus-8 (HHV-8) infection: MCD for the presence and idiopathic MCD (iMCD) for the absence. $^{12}$

Although it is rare, skin manifestation such as violaceous plaques can be associated with iMCD, and such associated cases have been mostly reported from Asian countries with a histopathological finding of cutaneous plasmacytosis. ${ }^{3}$

Long-term asymptomatic phase with only cutaneous manifestations before the development of systemic inflammatory symptoms of iMCD has been reported in a small number of cases. Furthermore, the role of tocilizumab for the treatment of iMCD with cutaneous manifestations still remains empirical. Accumulation of cases is required to elucidate characteristics and natural history of iMCD.

We here report a rare case of iMCD along with literature review.

\section{CASE PRESENTATION}

A 45 -year-old woman was referred from the dermatology department of our hospital because of fever, weight loss and general malaise of 1-month duration. One and a half years previously, she noticed multiple small violaceous plaques on her forehead and chest. The plaques were neither painful nor pruritic. Half a year later, the plaques became more violaceous, increased in number and spread to the abdomen. Skin biopsy of the plaque showed infiltration of lymphocytes and plasma cells, and immunohistochemical study excluded malignant lymphoma. She was treated with topical steroid and phototherapy by excimer light, which did not improve the plaques.

About 1 month before the referral, she developed a low-grade fever and general malaise. The fever occasionally worsened to a high-grade fever 1 week previously and she lost $5 \mathrm{~kg}$ of body weight in 1 month.

On physical examination, the body temperature was $37.1^{\circ} \mathrm{C}$. There were $5-10 \mathrm{~mm}$ violaceous plaques on the forehead, chest, abdomen, back and extremities (figure 1). Painful lymph nodes of 1-2 $\mathrm{cm}$ in diameter were palpable in the cervical, axillar and inguinal regions. The remainder of the physical examination was unremarkable.

\section{INVESTIGATIONS}

Laboratory results were significant for anaemia (haemoglobin $86 \mathrm{~g} / \mathrm{L}$ ), elevated liver enzymes (alkaline phosphatase: $605 \mathrm{IU}$, aspartate transaminase: 318 IU and alanine transaminase: 346 IU), polyclonal hypergammaglobulinaemia (immunoglobulin $\mathrm{G}(\mathrm{IgG})$ : $3515 \mathrm{mg} / \mathrm{dL}, \operatorname{IgA}: 393 \mathrm{mg} / \mathrm{dL}$ and IgM: $370 \mathrm{mg} / \mathrm{dL}$ ), high inflammatory markers (C reactive protein: $12.6 \mathrm{mg} / \mathrm{dL}$ and erythrocyte sedimentation rate $65 \mathrm{~mm} /$ hour) and elevated interleukin-6 (IL-6: $111 \mathrm{pg} / \mathrm{mL}$; normal range: $<5 \mathrm{pg} /$ $\mathrm{mL})$. Serum IgG subclass 4 concentration and $\operatorname{Ig} \kappa / \lambda$ free light chain ratio were normal. Tests for HIV and PCR for HHV-8 were negative. Antinuclear antibody, rheumatoid factor and anti-Ro/SSA and anti-La/SSB antibodies were all negative.

CT with contrast enhancement revealed multiple swollen superficial lymph nodes of 1 to $2 \mathrm{~cm}$ in diameter and splenomegaly. Positron emission tomography CT (PET-CT) showed increased uptake in the cervical, axillary and inguinal lymph nodes, the sternum, the vertebrae and the pelvic bone (figure 2). 


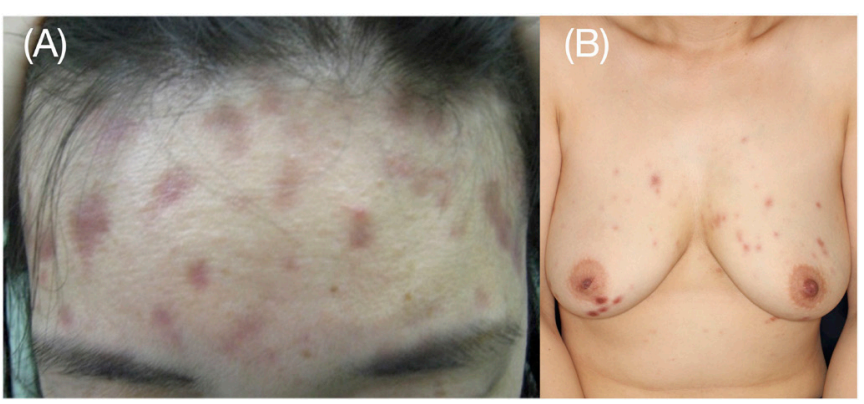

Figure 1 Skin plaques before treatment $(A)$ forehead and $(B)$ trunk.

Biopsy of the inguinal lymph node selected based on the PET-CT result was performed. The histopathological finding of the lymph node was diffuse proliferation of mature-appearing plasma cells without evidence of malignancy, granulomatous diseases and necrotising lymphadenitis (figure 3). Immunohistochemical study of the lymph node specimen demonstrated polyclonal plasmacytosis. Skin biopsy of the plaque conducted again showed dermal infiltrate predominantly composed of polyclonal plasma cells and follicular hyperplasia (figure 4). Bone marrow aspiration study showed polyclonal plasma cell proliferation without evidence of multiple myeloma.

These biopsy findings of the specimens taken from the lymph node, the skin plaque and the bone marrow were consistent with plasma cell type of MCD.

\section{DIFFERENTIAL DIAGNOSIS}

The differential diagnoses included malignant lymphoma (eg, follicle centre lymphoma and cutaneous marginal zone B-cell lymphoma) and collagen vascular diseases, both of which can manifest multiple skin plaques and lymphadenopathies. Malignant lymphoma was excluded by the immunohistochemical study of the biopsy specimens. Collagen vascular diseases were excluded by clinical symptoms and laboratory data. Since there

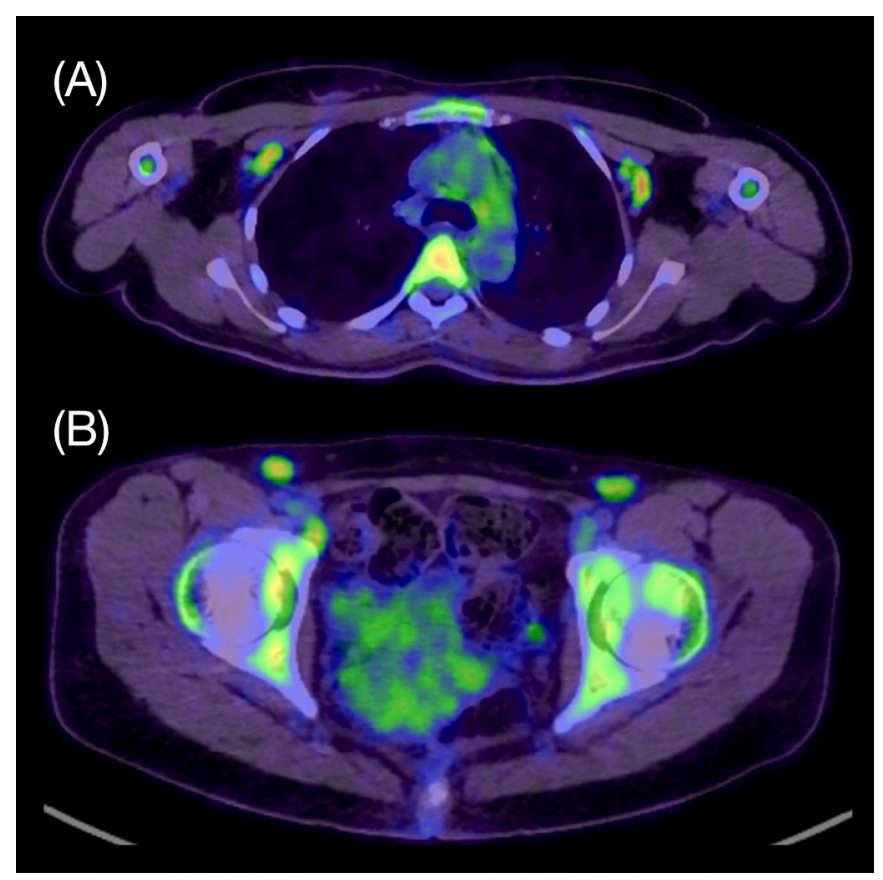

Figure 2 The positron emission tomography CT scan showed increased tracer uptake in multiple superficial lymph nodes. (A) Axillary lymph nodes. (B) Inguinal lymph nodes.
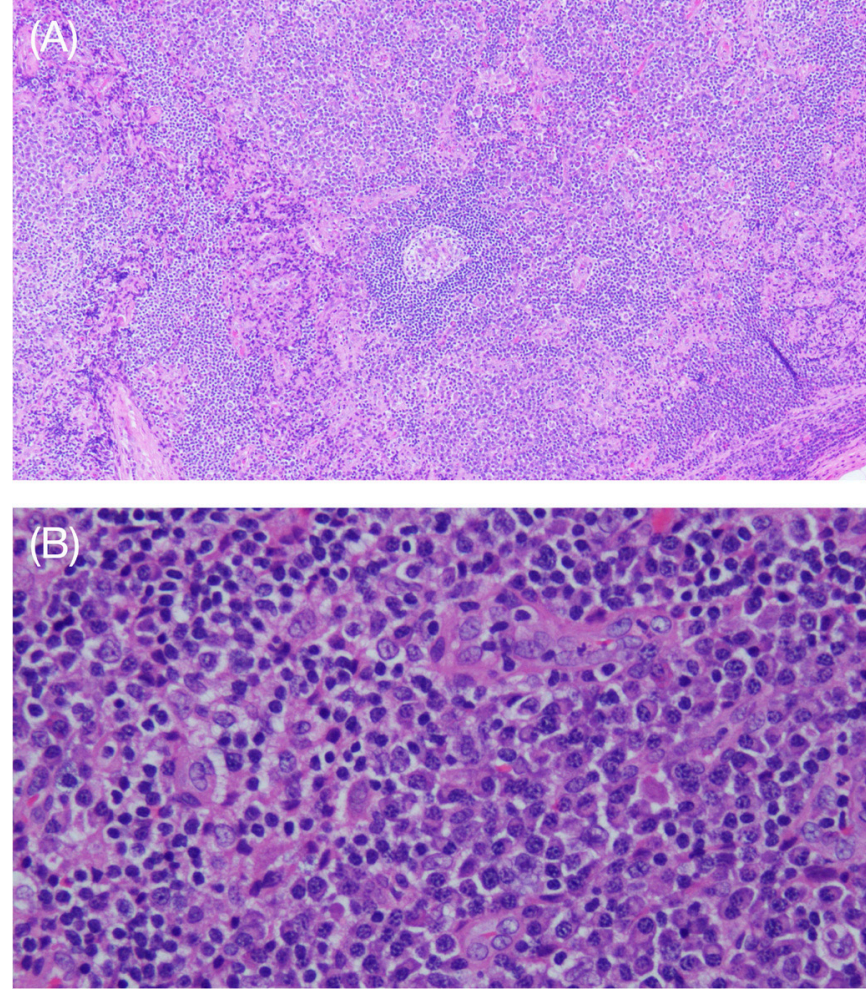

Figure 3 Histopathological findings of the left inguinal lymph node. (A) Hyperplastic germinal centres surrounded by sheet-like plasma cells (H\&E stain, magnification $\times 40$ ). (B) Plasma cell proliferation in the interfollicular areas (H\&E stain, magnification $\times 200$ ).

was no evidence of HHV-8 infection, the patient was diagnosed with iMCD with cutaneous and bone marrow plasmacytosis. The cutaneous manifestations without constitutional symptoms were considered to be the asymptomatic phase preceding iMCD.

\section{TREATMENT}

Prednisolone $(50 \mathrm{mg}$ ) was initiated. Fever and general malaise subsided with gradual improvement of anaemia and inflammatory markers. The skin lesions relatively decreased in number with residual slight violaceous pigmentation. However, inflammatory markers began to rise after prednisolone was tapered to $10 \mathrm{mg}$. Anti-IL-6 receptor antibody, tocilizumab, was initiated 11 months after the initiation of the steroid treatment.

\section{OUTCOME AND FOLLOW-UP}

The skin lesions were dramatically diminished (figure 5), and the inflammatory markers returned to normal level. There is no recurrence after 10 months of the treatment of tocilizumab.

\section{DISCUSSION}

In 1956, Benjamin Castleman first reported 13 cases presenting with mediastinal lymphadenopathy and described a heterogeneous non-malignant lymphoproliferative disorder, later named Castleman disease. ${ }^{1}$ The disease is classified depending on whether it is localised to a single lymph node (unicentric Castleman disease) or extended to multiple areas (MCD). MCD causes systemic inflammatory symptoms, lymphoproliferation, cytopenias and multiple organ damage due to the excess of proinflammatory cytokines, especially IL-6. Histopathological features of MCD include plasma cell hyperplasia and hypervascularity of the affected tissues. ${ }^{4}$ MCD is further divided into two 

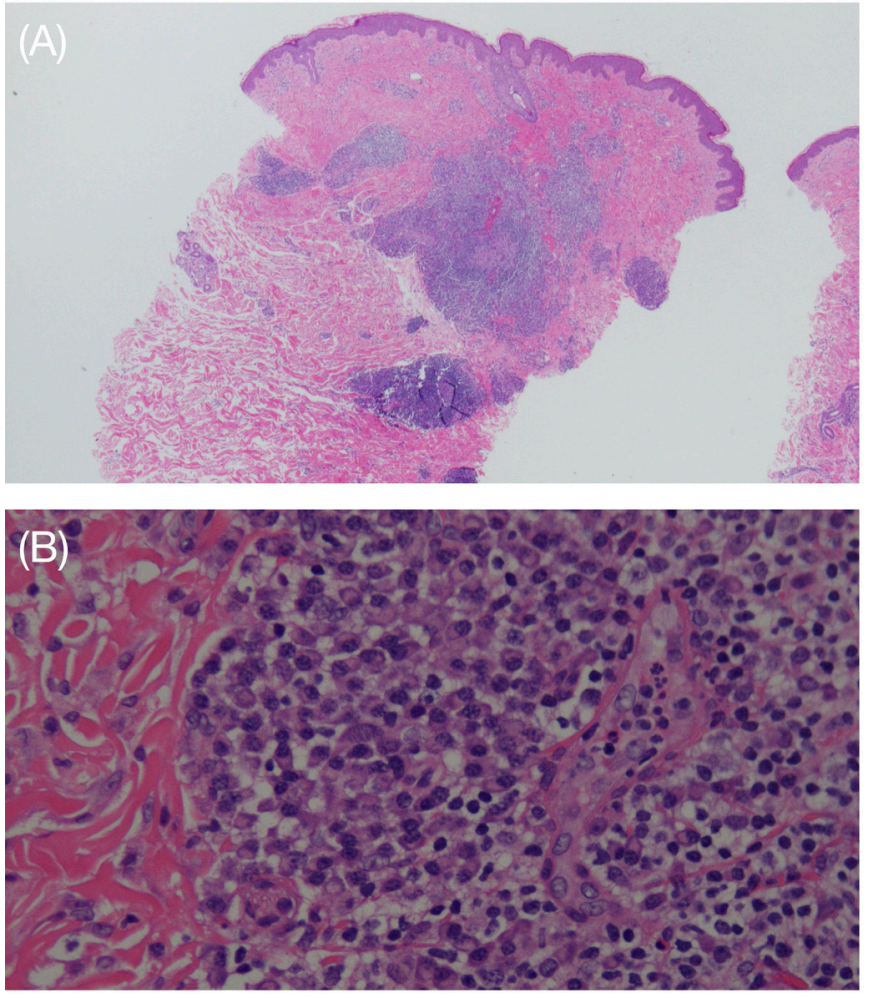

Figure 4 Histopathological findings of the skin. (A) Proliferation of lymphoid follicles under the epithelium with increased lymphocytes and mature plasma cells (H\&E stain, magnification $\times 4$ ). (B) Diffuse plasma cell proliferation with sheet-like appearance (H\&E stain, magnification $\times 200$ ).

subtypes according to the presence or absence of HHV-8 infection. MCD associated with HHV-8 is also known as Kaposi's sarcoma-associated herpesvirus and frequently found in patients with HIV infection. HHV-8 produces viral IL-6, which is similar to human IL-6 and causes HHV-8-associated MCD. ${ }^{5}$ The other subtype, which is not associated with HHV-8 infection but its clinical and histopathological features are identical to those of $\mathrm{HHV}$-8-associated MCD, is called iMCD.

Consensus diagnostic criteria for iMCD established by the Castleman Disease Collaborative Network in 2013 added dermatological findings of 'eruptive cherry hemangiomatosis or violaceous papules' to the clinical minor criteria after the accumulation of iMCD cases presenting with skin lesions in the form of cutaneous and systemic plasmacytosis (CSP), mostly reported from Asian countries. ${ }^{6}$ Histopathology of CSP is identical to that of plasma-cell-type MCD, and both diseases partially share the same pathogenesis and have high levels of cytokinaemia, including IL-6. Suggestion was, therefore, made that CSP was a variant of plasma-cell-type MCD. ${ }^{7}$

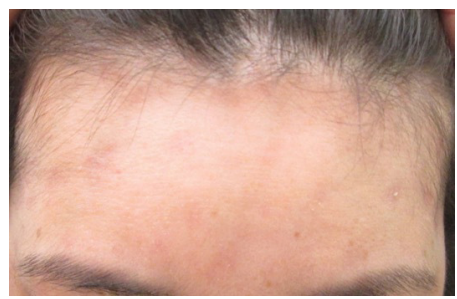

Figure 5 Skin plaques after treatment with tocilizumab.
Table 1 Reported cases of iMCD preceded by cutaneous plasmacytosis*

\begin{tabular}{|c|c|c|c|c|}
\hline Author & $\begin{array}{l}\text { Age } \\
\text { (years) }\end{array}$ & Sex & $\begin{array}{l}\text { Asymptomatic } \\
\text { periodt (years) }\end{array}$ & $\begin{array}{l}\text { Location of skin } \\
\text { plaques }\end{array}$ \\
\hline Kubota et $a \beta^{3}$ & 57 & $M$ & 15 & Face and trunk \\
\hline Klein et $a l^{11}$ & 44 & $\mathrm{~F}$ & NA & Trunk and extremities \\
\hline Arai et al ${ }^{12}$ & 33 & $\mathrm{~F}$ & 9 & Face and trunk \\
\hline Kayasut et al ${ }^{7}$ & 71 & $\mathrm{M}$ & NA & Trunk \\
\hline Ahmed et $a l^{13}$ & 42 & $\mathrm{~F}$ & 7.5 & Face and trunk \\
\hline Higashi et $a l^{14}$ & 39 & $\mathrm{~F}$ & 6 & Face and trunk \\
\hline Higashi et al ${ }^{14}$ & 46 & $\mathrm{M}$ & 10 & $\begin{array}{l}\text { Face, trunk and } \\
\text { extremities }\end{array}$ \\
\hline $\begin{array}{l}\text { Okuyama et } \\
\text { al } l^{15}\end{array}$ & 45 & $\mathrm{~F}$ & 3 & Trunk \\
\hline $\begin{array}{l}\text { Okuyama et } \\
\text { al } 1^{15}\end{array}$ & 36 & $\mathrm{~F}$ & 2 & Trunk \\
\hline Park et $a l^{16}$ & 65 & $\mathrm{M}$ & 7 & $\begin{array}{l}\text { Head, trunk and } \\
\text { extremities }\end{array}$ \\
\hline Honda et al ${ }^{17}$ & 45 & $\mathrm{~F}$ & 8 & Trunk \\
\hline Our case & 45 & $\mathrm{~F}$ & 1.5 & Face and trunk \\
\hline
\end{tabular}

NA; Not available.

*Two cases without histological confirmation of the lymph nodes were excluded. †The period with only skin lesions before the occurrence of systemic symptoms. F, female; iMCD, idiopathic multicentric Castleman disease; M, male.

The consensus guideline recommends an anti-IL-6 monoclonal antibody, siltuximab, with or without corticosteroid as the first-line therapy for iMCD regardless of disease severity. ${ }^{8}$ Tocilizumab, a monoclonal antibody against IL-6 receptor, is also recommended as an alternative if siltuximab is not available. Corticosteroid monotherapy is not recommended because of its high treatment failure rate and frequent relapses. There is no specific recommendation for the treatment of iMCD preceded by cutaneous manifestations.

According to the literature search we conducted, MCD cases preceded by skin lesions were rarely reported. There were only 11 cases of MCD with preceding skin lesions confirmed by lymph node biopsy after excluding two cases without histological confirmation of lymph nodes, a definitive diagnostic criterion of MCD (table 1 ).

All these 11 cases were of iMCD. Histopathological features of their skin lesions included polyclonal lymphoplasmacytic infiltration in the form of cutaneous plasmacytosis. Medical management in asymptomatic periods focused on only skin problems.

The duration of the asymptomatic period with only skin lesions varied from 2 years to 15 years with the median duration of 7.5 years (IQR: 6 years and 9 years). However, the asymptomatic period in our case was 1.5 years, which was shorter than any other cases previously reported.

Humanised IL-6 receptor monoclonal antibody is a key drug for iMCD, and tocilizumab is currently approved for the treatment of iMCD in Japan. ${ }^{9}$ However, the effectiveness of tocilizumab for iMCD preceded by cutaneous plasmacytosis was unclear. In the literature review, prednisolone was used for the treatment of iMCD preceded by cutaneous plasmacytosis in all cases. However, glucocorticoid monotherapy for iMCD is reported to provide only mild symptom relief and incomplete remission with frequent relapses during steroid tapering, as seen in our case. To the best of our knowledge, there has been only one case report of iMCD preceded by cutaneous plasmacytosis successfully treated with tocilizumab. ${ }^{10}$ Our case was successfully treated with tocilizumab after incomplete remission by prednisolone treatment. This suggests that anti-IL-6 therapy can be the 
first-line treatment of iMCD preceded by cutaneous plasmacytosis, in addition to its current use as the first-line treatment for iMCD without skin lesions.

In summary, we suggest that a careful follow-up is required in all asymptomatic patients with cutaneous plasmacytosis to monitor the development of $\mathrm{MCD}$, and that the therapy against human IL-6 can be the first-line treatment for this type of iMCD.

\section{Patient's perspective}

At first, some primary care doctors told me that the violaceous spots on my forehead were simply due to an age-related skin problem. However, I was extremely anxious about whether I had some terrible disease, because the spots gradually increased in number and started to appear on my chest as well. In particular, when I had a high-grade fever, my anxiety increased every day. It reached the point where I thought I was going to die of the disease if these symptoms were not improved. At this point, I was referred to your department, and the diagnosis of idiopathic multicentric Castleman disease was made. Although I was initially shocked to find out that I had such a rare and intractable illness, all I could do was just trust my physicians and receive my treatment of prednisolone and tocilizumab. Now, thanks to the treatment, my concerns, as well as my symptoms, have almost gone, with no fever and no visible spots. I am happy that I can work at my job as much as I did before. I deeply appreciate the continued effort and care of my physicians.

\section{Learning points}

- Cutaneous plasmacytosis is a rare manifestation of idiopathic multicentric Castleman disease (iMCD).

- Asymptomatic patients with cutaneous plasmacytosis require monitoring for the development of iMCD.

- Anti-interleukin-6 treatment can also be the first choice for patients with iMCD preceded by cutaneous plasmacytosis.

Acknowledgements We would like to thank Dr Osamu Suzuki for pathological findings.

Contributors TA wrote the manuscript draft and conducted the literature review. The manuscript was reviewed by YS and YN. SH edited the manuscripts and finally confirmed it. All authors did clinical management for the patient.

Funding The authors have not declared a specific grant for this research from any funding agency in the public, commercial or not-for-profit sectors.

Competing interests None declared.
Patient consent for publication Obtained.

Provenance and peer review Not commissioned; externally peer reviewed.

Open access This is an open access article distributed in accordance with the Creative Commons Attribution Non Commercial (CC BY-NC 4.0) license, which permits others to distribute, remix, adapt, build upon this work non-commercially, and license their derivative works on different terms, provided the original work is properly cited and the use is non-commercial. See: http://creativecommons.org/ licenses/by-nc/4.0/.

\section{ORCID iD}

Sugihiro Hamaguchi http://orcid.org/0000-0001-9926-8098

\section{REFERENCES}

1 Castleman B, Iverson L, Menendez VP. Localized mediastinal lymphnode hyperplasia resembling thymoma. Cancer 1956;9:822-30.

2 Fajgenbaum DC, van Rhee F, Nabel CS. HHV-8-negative, idiopathic multicentric Castleman disease: novel insights into biology, pathogenesis, and therapy. Blood 2014;123:2924-33.

3 Kubota Y, Noto S, Takakuwa T, et al. Skin involvement in giant lymph node hyperplasia (Castleman's disease). J Am Acad Dermatol 1993;29:778-80.

4 Keller AR, Hochholzer L, Castleman B. Hyaline-vascular and plasma-cell types of giant lymph node hyperplasia of the mediastinum and other locations. Cancer 1972;29:670-83.

5 Direkze S, Laman H. Regulation of growth signalling and cell cycle by Kaposi's sarcoma-associated herpesvirus genes. Int J Exp Pathol 2004;85:305-19.

6 Fajgenbaum DC, Uldrick TS, Bagg A, et al. International, evidence-based consensus diagnostic criteria for HHV-8-negative/idiopathic multicentric Castleman disease. Blood 2017:129:1646-57.

7 Kayasut K, Le Tourneau A, Rio B, et al. Are multicentric Castleman's disease with cutaneous plasmacytosis and systemic plasmacytosis the same entity? Histopathology 2006;49:557-8.

8 van Rhee F, Voorhees P, Dispenzieri A, et al. International, evidence-based consensus treatment guidelines for idiopathic multicentric Castleman disease. Blood 2018;132:2115-24.

9 Nishimoto N, Kanakura Y, Aozasa K, et al. Humanized anti-interleukin-6 receptor antibody treatment of multicentric Castleman disease. Blood 2005;106:2627-32.

10 Sangawa M, Nagai H, Katayama Y, et al. Long-term therapeutic effects of tocilizumab on cutaneous plasmacytosis associated with multicentric Castleman's disease. Hihubyoshinryo 2018:40:587-90.

11 Klein WM, Rencic A, Munshi NC, et al. Multicentric plasma cell variant of Castleman's disease with cutaneous involvement. J Cutan Pathol 2004;31:448-52.

12 Arai E, Shimizu M, Hirose T, et al. A case of multicentric Castleman's disease, initially manifested in the skin, with a long follow-up study. Skin Cancer 2005;20:171-5.

13 Ahmed B, Tschen JA, Cohen PR, et al. Cutaneous Castleman's disease responds to anti interleukin-6 treatment. Mol Cancer Ther 2007;6:2386-90.

14 Higashi Y, Kanekura T, Sakamoto R, et al. Multicentric Castleman disease with cutaneous manifestations: report of 2 cases and comparison with systemic plasmacytosis. Dermatology 2007;214:170-3.

15 Okuyama R, Harigae H, Moriya T, et al. Indurated nodules and plaques showing a dense plasma cell infiltrate as a cutaneous manifestation of Castleman's disease. $\mathrm{Br} J$ Dermatol 2007;156:174-6.

16 Park H-Y, Lee J-J, Lee J-B, et al. Castleman's disease with cutaneous involvement Manifestating as multiple Violaceous plaques on entire body. Ann Dermatol 2011;23:S169-74.

17 Honda R, Cerroni L, Tanikawa A, et al. Cutaneous plasmacytosis: report of 6 cases with or without systemic involvement. J Am Acad Dermatol 2013;68:978-85.

Copyright 2020 BMJ Publishing Group. All rights reserved. For permission to reuse any of this content visit

https://www.bmj.com/company/products-services/rights-and-licensing/permissions/

BMJ Case Report Fellows may re-use this article for personal use and teaching without any further permission.

Become a Fellow of BMJ Case Reports today and you can:

- Submit as many cases as you like

- Enjoy fast sympathetic peer review and rapid publication of accepted articles

- Access all the published articles

Re-use any of the published material for personal use and teaching without further permission

Customer Service

If you have any further queries about your subscription, please contact our customer services team on +44 (0) 2071111105 or via email at support@bmj.com.

Visit casereports.bmj.com for more articles like this and to become a Fellow 